\title{
PENGGUNAAN JENIS LARO TERHADAP PERBEDAAN ORGANOLEPTIK DAN pH NIRA SIWALAN
}

\author{
Ismawati $^{1}$, Ratih Yuniastri ${ }^{2}$ \\ Program Studi Teknologi Hasil Pertanian Universitas Wiraraja Sumenep \\ ismawati@wiraraja.ac.id, ratihyuniastri@wiraraja.ac.id
}

\begin{abstract}
Laro is one of the natural preservatives of siwalan juice made from tree bark which is mixed after being roughly ground. This research used laro bark of cashew trees and tree bark. The aim of the study was to determine the quality of siwalan juice using different types of laro. The treatment in the study was the use of laro types including siwalan juice without the use of laro, siwalan nira using laro tree bark and siwalan nira using laro from the skin of cashew trees. Of the three treatments, different pairs of tests were carried out on taste, color, aroma and turbidity and $\mathrm{pH}$ test. The results showed that there were differences in taste, color, aroma, turbidity and $\mathrm{pH}$ of siwalan juice from each treatment. The best treatment for the quality of siwalan sap is by using cashew laro.
\end{abstract}

Keywords: laro, organoleptic, $\mathrm{pH}$, siwalan juice

\section{PENDAHULUAN}

Nira siwalan merupakan salah satu bahan baku gula merah atau gula jawa. Nira siwalan berasal dari pohon siwalan khususnya bagian tangkai tandan bunga yang didapatkan melalui proses penyadapan selama kurang lebih 10 jam. Tandan bunga yang disadap adalah tandan bunga jantan sedangkan tandan bunga betina tidak disadap akantetapi dibiarkan menjadi buah siwalan. Di Indonesia daerah penghasil siwalan tersebar di beberapa wilayah diantaranya adalah Jawa Timur khususnya pulau Madura, Jawa Tengah, Bali, Nusa Tenggara Barat, Nusa Tenggara Timur dan Sulawesi.

Nira siwalan termasuk salah satu bahan hasil pertanian yang memiliki kandungan nutrisi lengkap seperti protein, mineral, air dan karbohirat. Kompleksnya kandungan nutrisi nira siwalan menyebabkan nira siwalan mudah rusak sehingga perlu dilakukan penanganan yang tepat. Pada umumnya masyarakat lokal memanfaatkan bahan alami untuk memperlambat proses kerusakan nira yang biasanya disebut dengan laro.

Laro adalah kulit pohon yang di tumbuk kasar dan ditambahkan dalam nira siwalan dengan tujuan menstabilkan $\mathrm{pH}$ dan memperlambat proses fermentasi alami pada nira siwalan. Kulit pohon yang digunakan sebagai laro berbeda-beda diantaranya adalah kulit pohon jambu mete, kulit pohon jaran dan kulit pohon kosambhi. Dari ketiga jenis laro tersebut yang paling banyak digunakan oleh masyarakat adalah laro dari kulit pohon mete dan kulit pohon kayu jaran. Kedua pohon tersebut sama-sama mudah 
didapatkan karena ketersediaannya melimpah.

Pohon jambu mete adalah jenis pohon yang dikenal memiliki banyak manfaat yang salah satunya untuk mengobati sariawan. Penggunaan kulit pohon jambu mete dikenal oleh masyarakat dapat memperlambat proses fermentasi alami gula pada nira dan memperlambat penurunan $\mathrm{pH}$ sehingga nira menjadi lebih awet dan rasa manis dari nira dapat dipertahankan. Fardiaz dalam Suroyya (2016) menyebutkan bahwa nira yang dibiarkan pada suhu kamar akan mengalami proses peragian yaitu fermentasi gula dalam nira menjadi alkohol oleh mikroorganisme dalam nira dan oksidasi alkohol menjadi asam asetat.

Penggunaan kulit pohon sebagai laro untuk memperpanjang umur simpan nira disebabkan kulit pohon mengandung senyawa tanin yang dapat bersifat antimikroba, antifungi dan dapat menghambat adsorbsi pada khamir. Mekanisme aktivitas antibaktei pada tanin yaitu dengan cara menghambat enzim reverse transkriptase dan DNA topoisomerase yang dapat meyebabkan kerusakan pada sel bakteri (Sorayya, 2016). Naufalin (2013) menyebutkan bahwa kulit pohon selain bersifat antimikroba juga mengandung senyawa antioksidan yaitu tanin.

Penambahan laro pada nira selain sebagai penghambat proses fermentasi juga berfungsi menghambat terjadinya penurunan $\mathrm{pH}$ yang dapat mempengaruhi sifat organoleptik nira. Berdasarkan hal tersebut
E-ISSN: XXXX-XXXX

maka perlu dilakukan penelitian perbedaan organoleptik nira siwalan yang diberi laro berbeda. Maka penelitian ini bertujuan untuk mengetahui perbedaan organoleptik nira siwalan serta perbedaan $\mathrm{pH}$ nira siwalan yang diberi laro kulit pohon jaran, kulit pohon mete serta siwalan tanpa laro.

\section{METODE PENELITIAN}

\section{Alat dan Bahan}

Alat yang digunakan pada penelitian ini diantaranya $\mathrm{pH}$ meter, gelas ukur, spatula, botol plastik dan gelas plastik. Adapun bahan yang digunakan adalah nira siwalan yang didapatkan dari Desa Longos Kecamatan Gapura Kabupaten Sumenep. Nira siwalan yang digunakan pada uji beda adalah nira siwalan yang masih segar. Penelitian dilaksanakan di Laboratorium Mikrobiologi Program Studi Teknologi Hasil Pertanian Fakultas Pertanian Universitas Wiraraja Sumenep. Penelitian dilaksanakan pada bulan Oktober 2018.

Terdapat 3 jenis nira siwalan yang diuji beda diantaranya nira siwalan tanpa penggunaan laro, nira siwalan menggunakan laro kulit pohon jaran dan nira siwalan menggunakan laro dari kulit pohon mete. Dari 3 jenis nira siwalan tersebut diuji perbedaan organoleptik masing-masing pasangan sama dan berbeda sehingga dilakukan uji beda terhadap 3 pasang sampel yang berbeda.

Pada uji beda pertama disajikan sampel yang berbeda yaitu nira siwalan tanpa laro dan nira siwalan dengan laro kulit pohon jaran sedangkan sampel yang 
sama yaitu nira siwalan dengan laro kulit pohon jaran (pasangan sampel 1).

Selanjutnya dilakukan uji beda pada sampel nira siwalan tanpa laro dan nira siwalan dengan laro kulit pohon mete sebagai sampel pembeda dan sampel yang sama yaitu nira siwalan dengan laro kulit pohon mete (pasangan sampel 2). Sampel yang diuji beda yang ketiga adalah nira siwalan dengan laro kulit pohon jaran dan nira siwalan dengan laro kulit pohon mete (pasangan sampel 3). Uji beda segitiga dilakukan terhadap parameter organoleptik nira diantaranya warna, kekeruhan, aroma dan rasa.

Tahapan yang dilakukan dalam poses penentuan panelis yaitu tahap seleksi panelis yang dimulai dari pengisian formulir pendaftaran uji panelis, wawancara dan uji coba. Tahap uji coba adalah tahapan dimana panelis uji kepekaan pancaindera dengan menggunakan uji beda segitiga yaitu panelis diharuskan mampu menemukan sampel yang sama dari berbagai sampel yang disajikan. Panelis dianggap telah memenuhi persyaratan apabila mampu mendeteksi dengan benar produk yang berbeda ataupun sama dari beberapa produk yang diujikan (Anonim, 2006).

Jumlah panelis 31 orang sehingga dapat dikatakan telah melebihi jumlah panelis minimal pada uji beda. Lawless dan Heyman (2010) menyebutkan bahwa dalam uji beda dapat menggunakan panelis sejumlah 25-40. Untuk dapat menyatakan bahwa sampel berbeda atau tidak, maka hasil respon panelis dibandingkan dengan tabel statistik uji beda.
E-ISSN: XXXX-XXXX

Uji $\mathrm{pH}$ dilakukan setelah nira siwalan dibiarkan dalam waktu 5 jam pada suhu ruang setelah proses penyadapan. Pengujian $\mathrm{pH}$ dilakukan terhadap 3 sampel nira siwalan yaitu nira siwalan tanpa laro, nira siwalan menggunakan laro kulit pohon jaran dan nira siwalan menggunakan kulit pohon mete dan masing masing diulang hingga tiga kali.

\section{HASIL DAN PEMBAHASAN Perbedaan Organoleptik Nira Siwalan}

Pada tahap uji organoleptik bentuk penyajian sampel dilakukan secara seksama agar sampel tersaji dengan seragam baik dari satu sampel pembeda maupun dua sampel yang sama. Pada proses pengujian sampel, panelis dipandu untuk mengisi kuesioner bagian penilaian indera penglihatan terlebih dahulu, kemudian penciuman (aroma) dan dilanjutkan dengan uji indera perasa.

\begin{abstract}
Hasil uji organoleptik terhadap perbedaan rasa, aroma, warna dan kekeruhan nira siwalan dengan penggunaan jenis laro dan tanpa laro. Panelis dalam penelitian terdiri dari 31 orang. Pada uji beda terhadap dua sampel yang berbeda yaitu nira siwalan tanpa laro dan nira siwalan laro pohon jaran pada parameter warna semua panelis yang berjumlah 31 mengatakan berbeda.
\end{abstract}

Berdasarkan jumlah pernyataan berbeda dari 31 panelis maka dapat diambil kesimpulan bahwa kedua sampel tersebut dapat dikatakan berbeda sebagaimana pada kriteria pada tabel triangle test dengan jumlah panelis 31 pada signifikansi 5\% adalah 16 panelis yang menjaawab berbeda 
dan pada signifikansi $1 \%$ adalah 18 panelis yang harus menyatakan berbeda.

Nira siwalan yang masih segar memiliki rasa manis yang disebabkan adanya kandungan gula yang cukup tinggi yaitu berkisar antara 10-20\%. Kandungan gula yang tinggi pada nira siwalan menjadikan nira siwalan cepat mengalami perubahan rasa manis menjadi kecut akibat terjadinya proses fermentasi jika didukung oleh kondisi lingkugan yang sesuai bagi pertumbuhan mikrooganisme.

Nira yang diberikan laro dari kulit pohon jaran dan kulit pohon mete masih berasa manis pada waktu pengujian organoleptik sedangkan nira siwalan tanpa laro memiliki rasa manis dan sedikit kecut. Nira siwalan yang digunakan dalam uji organoleptik tidak benar-benar segar karena lokasi pengambilan nira yang cukup jauh dan persiapan uji organoleptik akhirnya nira mengalami proses penyimpanan selama 2 jam. Oleh sebab itu pada nira tanpa laro sudah mulai mengalami perubahan rasa dari manis menjadi manis-kecut, sedangkan nira yang menggunakan laro masih berasa manis (sama dengan nira segar).

Hasil penelitian Silabani et al (2017) pada jam ke 2 -8 terjadi log phase pada proses fermentasi nira siwalan menggunakan mikroorganisme khamir dan bakteri. Berdasarkan hal tersebut maka dalam penelitian ini nira siwalan tanpa laro juga mulai terjadi proses fermentasi yang menyebabkan rasa dan aroma berubah menjadi kecut dan mulai muncul aroma cuka. Artinya aktivitas mikroba berlangsung lebih cepat pada nira siwalan tanpa menggunakan laro.
E-ISSN: XXXX-XXXX

Adanya perubahan rasa dan aroma pada nira menandakan terjadinya kerusakan nira. Salah satu indikator kerusakan nira lainnya adalah adanya penurunan $\mathrm{pH}$. Penurunan $\mathrm{pH}$ mengakibatkan perubahan rasa manis menjadi kecut atau asam. Nira siwalan mengandung nutrisi yang kompleks sehingga sangat cepat mengalami kerusakan yang berupa perubahan rasa maupun aroma. Hal itu disebabkan adanya proses perombakan gula menjadi alkohol dan asam organik oleh khamir maupun bakteri sebagai hasil dari proses fermentasi (Eka dan Halim, tanpa tahun). Terbentuknya senyawa ini menyebabkan peningkatan kadar asam dalam nira yang menyebabkan perubahan rasa menjadi lebih masam atau kecut. Jenis gula yang terkandung dalam nira siwalan yang paling tinggi yaitu fruktosa (199 g/l) kemudian glukosa $(154 \mathrm{~g} / \mathrm{l})$ dan sukrosa (105 g/l) ( Silabani et al, 2017).

Nira siwalan menggunakan laro kulit pohon jaran dan laro kulit pohon mete memiliki rasa yang manis. Hal ini disebabkan karena penambahan laro dapat memperlambat terjadinya fermentasi. Kandungan senyawa bioaktif yang terdapat dalam kulit pohon yang digunakan sebagai laro dapat menghambat aktivitas mikroba, sehingga rasa dari nira siwalan dengan laro masih dapat terjaga (Naufalin, 2013).

Aroma nira siwalan yang diberi laro kulit pohon jaran dan nira siwalan menggunakan laro kulit pohon mete tidak terdapat perbedaan aroma, akan tetapi panelis menyatakan adanya perbedaan aroma antara nira siwalan tanpa laro dan nira siwalan dengan laro. Data hasil uji beda sebagaimana disajikan pada Tabel 1 . 
Tabel 1. Hasil Uji Beda Nira Siwalan Berbagai Perlakuan

\begin{tabular}{llll} 
Pasangan Uji & Warna & Aroma & Rasa \\
\hline Tanpa laro \& Laro kulit pohon mete & berbeda & berbeda & Berbeda \\
Tanpa laro \& Laro kulit pohon jaran & berbeda & berbeda & Berbeda \\
Laro kulit pohon jaran \& Laro kulit pohon mete & berbeda & Tidak & Berbeda \\
& & berbeda &
\end{tabular}

Hasil uji beda terhadap warna nira dengan pembanding ira tanpa laro dan nira dengan laro kulit pohon mete menunjukkan dari ke 31 panelis semuanya menyatakan berbeda. Pada perbandingan nira tana laro dan nira menggunakan laro kulit pohon jaran sejumlh 31 panelis menyatakan berbeda sedangkan untuk nira yang menggunakan laro kulit pohon jaran dan kulit pohon mete juga dinyatakan berbeda oleh ke 31 panelis

Nira siwalan yang diberi laro kulit pohon jaran berwarna putih kekuningan sedangkan nira siwalan dengan laro kulit pohon mete berwarna putih kemerahan. Nira siwalan tanpa laro berwarna putih tulang.

Kekeruhan nira siwalan berbagai perlakuan dinilai berbeda oleh panelis. Nira siwalan tanpa laro lebih bening dibandingkan nira siwalan dengan dua perlakuan lainnya. Nira siwalan yang diberi laro lebih terlihat keruh, hal itu disebabkan adanya penambahan kulit pohon yang memberikan efek keruh terhadap nira siwalan.

Sejumlah 31 panelis menyatakan berbeda pada aroma nira tanpa laro dan nira dengan penggunaan laro kulit pohon mete demikian juga sejumlah 31 panelis menyatakan berbeda terhadap aroma nira tanpa laro dan nira dengan menggunakan laro kulit pohon jaran. Antara nira siwalan yang diberi laro kulit pohon jaran dan kulit pohon mete dinyaatakan tidak berbeda oleh 23 panelis sehingga berdasarkan tabel statistik triagle test kedua perlakuan dapat dinyatakan tidak berpengaruh terhadap aroma nira.

Nira siwalan tanpa laro memiliki aroma yang hampir mirip dengan aroma cuka. Hal itu disebabkan terjadinya proses fermentasi secara alami pada nira siwalan tanpa laro. Nira siwalan yang diberi dua jenis laro memiliki aroma yang sama dengan nira siwalan yang masih segar.

- Rasa nira siwalan dari masingmasing perlakuan dinilai berbeda berdasarkan hasil uji beda sebagaimana pada Tabel 1. Panelis yang menyatakaan berbeda terhadap pasangan nira siwalan tanpa laro dan nira siwalan dengan penambahan laro kulit mete yaitu berjumlah 19, sehingga dapat disimpulkan bahwa rasa nira berbeda. Panelis yang menyataakan berbeda terhadap rasa antara nira siwalan tanpa laro dan nira siwalan menggunakan laro kulit pohon mete yaitu sejumlah 29 sedangkan jumlah panelis yang menyatakan berbeda terhadap rsa nira siwalan dengan mengunakan laro kulit pohon jaran dan nira siwalan yang menggunakan laro kulit pohon mete sejumlah 25 panelis. 


\section{pH Nira Siwalan}

Rata-rata hasil uji $\mathrm{pH}$ nira siwalan ruang selama 5 jam setelah proses penyadapan disajikan pada Gambar 1 .

setelah dilakukan penyimpanan pada suhu

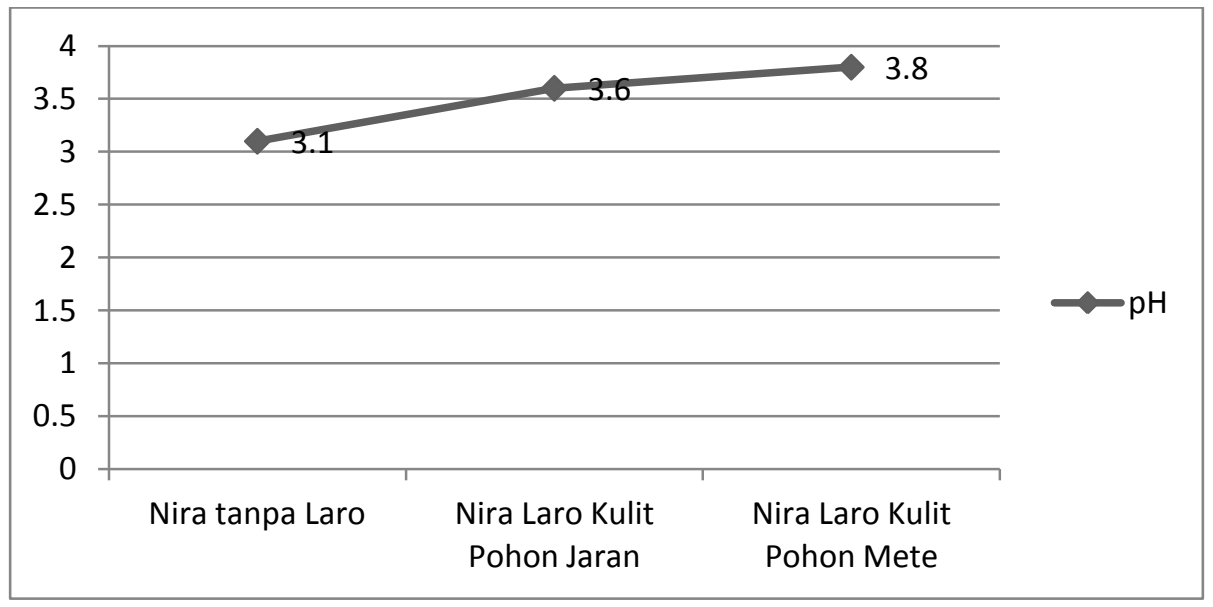

Gambar 1. Grafik pH Nira Siwalan Setelah 5 Jam Disimpan pada Suhu Ruang tumbuh yang baik bagi pertumbuhan mikroorganisme seperti Acetobacter acetic

Pada Gambar 1 dapat dilihat bahwa nira siwalan tanpa laro memiliki $\mathrm{pH}$ paling rendah yang artinya lebih asam dibandingkan dari dua sampel lainnya yang menggunakan laro. Fardiaz dalam (Sorayya, 2016) menyebutkan bahwa nira segar memiliki pH 5-6 dan berbau harum. Berdasarkan hal tersebut maka dapat dikatakan bahwa penggunaan laro dan perbedaan jenis laro dapat memberikan pengaruh pada penurunan $\mathrm{pH}$ nira siwalan $\mathrm{pH}$ nira siwalan segar adalah 5.1 dan selanjutnya terus mengalami penurunan hingga 3.97 selama penyimpanan pada suhu ruang dengan lama waktu 6 jam ( Imron et al, 2015).

Adanya waktu penyimpanan nira siwalan ini menyebabkan terjadinya penurunan $\mathrm{pH}$ nira siwalan. Penurunan $\mathrm{pH}$ ini disebabkan karena kandungan gula yang terkandung dalam nira merupakan media dan sel ragi dari genus Saccharomyces (Budiyanto dalam Lubis, 2013), yang mampu memfermentasi nira dan menyebabkan kerusakan pada nira. Reaksi fermentasi ini berlangsung secara spontan. Nira siwalan dengan laro memiliki $\mathrm{pH}$ yang lebih tinggi dibandingkan nira tanpa laro, artinya penggunaan laro pada nira siwalan mampu mempertahankan pH-nya walaupun terjadi sedikit penurunan.

\section{KESIMPULAN}

Dari hasil penelitian dapat disimpulkan bahwa penggunaan berbagai jenis laro memberikan efek perbedaan mutu organoleptik nira siwalan dan dapat menekan kenaikan pH. Perlakuan terbaik terhadap mutu organolepti nira siwalan adalah penggunaan jenis laro kulit jambu mete. 


\section{DAFTAR PUSTAKA}

Anonim. (2006). Pengujian Organoleptik (Evaluasi Sensori) Dalam Industri Pangan.

Eka, P. A., \& Halim, A. (t.thn.). Pembuatan Etanol dari Nira Siwalan Secara Fermentasi Fese Cair Menggunakan Fermipan.

Imron, S., Nugroho, A. W., \& Hendrawan, Y. (2015). Efektivitas Penundaan Proses Fermentasi pada Nira Siwalan (Borassus flabellifer L.) dengan Metode Penyinaan Ultra Violet. Jurnal Keteknikan Pertanian Tropis dan Biosistem, 259-269.

Lawles, H.T. and Heymann, H. (2010). Sensory Evaluation of Food: Principles and Practice, $2^{\text {th }}$ Ed. New York: Springer.

Lubis, R.F., Nainggolan, R.J., Nurminah, M. (2013). Pengaruh Penambahan Konsentrasi Bahan Pengawet Alami Pada Nira Aren Selama Penyimanan Terhadap Mutu Gula Aren Cair. Jurnal Rekayasa Pangan dan Pertanian, 1 (4): 76-82.

Naufalin, R., Yanto, T., dan Sulistyaningrum, A. (2013). Pengaruh Jenis dan Konsentrasi Pengawet Alami Terhadap Mutu Gula Kelapa. Jurnal Teknologi Pertanian, 14 (3): 165-174.

Silabani, M. J., Yuwono, L., \& Widjaja, T. (2017). Optimasi Fermentasi Produksi Etanol dari Nira Siwalan
(Borassus flabellifer) menggunakan Mikroorganisme Saccaromyces cerevisiae dan Pichia stipitis dengan Response Surface Methodology. Surabaya: Fakultas Teknologi Industri ITS.

Sorayya, M. (2016). Pengaruh Suhu dan Lama Penyimpanan terhadap Kualitas Nira siwalan (Borassus flabellifer I.) dengan Penambahan Ekstrak Biji Kelengkeng (Euphoria longan I.) . Universitas Islam Negeri Maulana Malik Ibrahim, Fakultas Sains dan Teknologi . Malang: Fakultas Sains dan Teknologi. 